\title{
SELECTED SCHOOL BASED FACTORS' INFLUENCE ON VALUE ADDITION IN SECONDARY EDUCATION IN PUBLIC SECONDARY SCHOOLS IN RACHUONYO SOUTH SUB-COUNY, HOMABAY COUNTY, KENYA
}

\author{
Phelix Almand Amoke ${ }^{1 \mathrm{i}}$, \\ James Ochieng Sika ${ }^{2}$ \\ ${ }^{1}$ Department of Education Management, \\ Maseno University, P.O. Box Private Bag, \\ Maseno, Kenya \\ ${ }^{2} \mathrm{PhD}$, Department of Education Management, \\ Maseno University, P.O. Box Private Bag, \\ Maseno, Kenya
}

\begin{abstract}
:
Educational accountability has mainly focused on final academic performance in judging schools' effectiveness without regard to where the students started. Judging schools' effectiveness solely based on final academic performance is unfair to school systems. Hence, the need to determine value addition in secondary education taking into consideration KCPE scores as intake abilities and KCSE scores as exit abilities. Moreover, public secondary schools in Rachuonyo South Sub-County recorded the highest negative academic progresses, -3.262 and -3.745, in the secondary education of 2013 and 2014 cohorts in Homa Bay County. However, the cause of the negative academic progresses is unknown. Hence, there is need to examine selected school-based factors' influence on value addition in the secondary education of the two cohorts. The objectives of the study are to examine performance appraisal's influence on value addition in secondary education; to examine continuous assessments' influence on value addition in secondary education and to examine classroom push and pull factors' influence on value addition in secondary education. A conceptual model developed from the basic model of school effectiveness by Scheerens (2000) and a correlational research design guided the study. The sample of the study comprised 49 Deputy Principals, 49 Directors of Studies and 780 students randomly sampled. Primary data were collected using questionnaires. Findings revealed that TPAD $(\beta=0.386, p=0.029)$ and $\operatorname{CPP}(\beta=0.364, p=0.034)$ have positive significant relationships with value addition, while CATs have insignificant relationship with value addition $\left(\beta_{1}=0.277, p=0.104\right)$ for 2013 cohort. For 2014 cohort, TPAD $(\beta=0.633$, $\mathrm{p}=0.000)$ and CATs $(\beta=0.356, \mathrm{p}=0.02)$ have positive significant relationships with value addition, while CPP has insignificant relationship with value addition $(\beta=0.22, p=0.136)$.
\end{abstract}

i Correspondence: email felixelmads@gmail.com, drjamessika@yahoo.com 
Moreover, findings revealed that school-based factors contributed to $19 \%$ and $38 \%$ variance in academic achievements of the 2013 and 2014 cohorts respectively. The findings of the study may be used as a tool for school improvement, checking school progress and accountability, informing policymaking, reporting to parents and the community about school.

Keywords: education; quality; value addition

\section{Introduction}

Quality education is crucial for addressing socioeconomic problems of poverty, unemployment and inequality (UNESCO, 2017). Similarly, African Development Bank (2014) recognizes the pivotal and important role of education in providing solution to mitigating unemployment and vulnerable unemployment among the youth. Reynolds et al. (2014) assert that quality education is crucial for addressing socioeconomic problems of poverty, unemployment and inequality in the society. Moreover, United Nations Education Scientific and Cultural Organization (UNESCO, 2013) recognizes the significant role of education in promoting economic growth and enhancing democracy and good governance in the world, thus calls the governments of the world to provide education that prepares the youth for knowledge intensive economies.

Montgomery (2012) asserts that performance appraisal is effective in increasing teachers' quality and productivity, which consequently improves students' academic achievements. Warokka, Gallato \& Moorthy (2012) assert that performance appraisal is done to improve teacher's performance. Kim et al. (2010) assert that teacher evaluation is conducted for professional development, performance management and rewarding outstanding teachers. In United States of America, a report issued for 2010 academic year revealed that only $6 \%$ of students performed well at the advanced level in mathematics, which was a percentage below those attained by 30 other participating countries (Hanushek, Peterson \& Woesman, 2012). In 2011 academic year, only 32\% of eight grade students were proficient in mathematics.

In Southern Africa, average test scores for literacy and numeracy are generally low with a considerable percentage of students failing to acquire basic skills in reading and mathematics. In Lesotho, by grade 6 only $48 \%$ of students achieved basic reading skills in 2011. In Zambia and Malawi, only $27 \%$ of students achieved basic reading skills in 2013, while in mathematics, the proportions of primary school students with basic skills is considerably low, with fewer than $50 \%$ of students in Grade 6 achieving the minimum level (UNESCO, 2014).

In Ghana, performance in the 2011 Trends in International mathematics and Science study (TIMSS) for students in eighth grade indicated low skills in level by ranking last at both math and science (Martin, Mullis, Foy \& Stanco, 2012). Moreover, Ghanaian students performed satisfactorily at the facts and procedures level, but failed in more advanced areas in problem solving, reasoning and using concepts. This indicates that the 
higher order skills needed to survive in the competitive global economy are not being developed in eighth grade.

In Tanzania, a report by the National Examinations Council of Tanzania (NECTA) revealed the pass rates (grade A to D) for the form four national examinations for 2007, 2008 and 2009 academic years for mathematics and science as follows: $31 \%, 24 \%$ and $18 \%$ in mathematics; $33 \%, 31 \%$ and $28 \%$ in chemistry; $46 \%, 41 \%$ and $43 \%$ in biology and $29 \%$, $26 \%$ and $27 \%$ in physics (Hamilton et al., 2010). This implies that the national performance in mathematics and sciences is below average in Tanzania.

In Kenya at the conclusion of primary education, pupils take KCPE examination, which is graded from 0 to 500 marks. At the conclusion of four years' secondary education, students take KCSE Examination, which is graded from $\mathrm{A}$ to E. Where, $\mathrm{A}($ plain $)=-12, \mathrm{~A}$ (minus $)=11, \mathrm{~B}$ (plus $)=10, \mathrm{~B}$ (plain $)=9, \mathrm{~B}$ (minus $)=8, \mathrm{C}($ plus $)=7, \mathrm{C}($ plain $)$ $=6, \mathrm{C}$ (minus) $=5, \mathrm{D}$ (plus) $=4, \mathrm{D}$ (plain) $=3, \mathrm{D}$ (minus) $=2$ and $\mathrm{E}=1$ (Amutabi, 2003).

In Homa Bay County, the mean performance at KCPE examinations deviated positively between 2013 and 2015. However, between 2016 and 2017, the mean performance at KCPE consistently declined (MoEST Office, Homa Bay County, 2018). Table 1 illustrates the performance trends in KCPE examinations in Homa Bay County between 2013 and 2017.

Table 1: KCPE Mean Performance in Homa-Bay County since 2013

\begin{tabular}{|l|c|c|c|c|c|}
\hline & \multicolumn{5}{|c|}{ Annual Mean Score } \\
\hline Sub-County & 2013 & 2014 & 2015 & 2016 & 2017 \\
\hline Rachuonyo South & 7.408 & 7.836 & 7.724 & 6.762 & 6.582 \\
\hline Rachuonyo North & 6.567 & 7.271 & 7.726 & 6.401 & 6.384 \\
\hline Homa Bay & 7.548 & 7.910 & 8.687 & 6.904 & 6.384 \\
\hline Ndhiwa & 6.234 & 6.728 & 7.123 & 6.136 & 6.021 \\
\hline Mbita & 6.486 & 6.662 & 7.269 & 6.386 & 6.189 \\
\hline Suba & 6.395 & 6.837 & 7.484 & 6.209 & 6.019 \\
\hline County Mean Score & 6.773 & 7.207 & 7.785 & 6.466 & 6.326 \\
\hline
\end{tabular}

Source: MoEST office, Homa Bay County (2018).

Likewise, in KCSE examinations, the mean score performance in Homa Bay County deviated positively between 2013 and 2015. However, in 2016 and 2017, the mean score performance dropped (MoEST Office, Homa Bay County, 2018). Table 2 below illustrates the performance trends in KCSE examinations in Homa Bay County between 2013 and 2017. 
Table 2: KCSE Mean Performance in Homa-Bay County since 2013

\begin{tabular}{|l|c|c|c|c|c|}
\hline & \multicolumn{5}{|c|}{ Annual Mean Score } \\
\hline Sub-County & 2013 & 2014 & 2015 & 2016 & 2017 \\
\hline Rachuonyo South & 5.599 & 6.024 & 6.346 & 4.146 & 4.091 \\
\hline Rachuonyo North & 5.450 & 5.806 & 5.938 & 3.941 & 3.316 \\
\hline Homa Bay & 6.337 & 6.805 & 6.906 & 4.248 & 4.227 \\
\hline Ndhiwa & 4.290 & 4.958 & 5.273 & 3.716 & 3.561 \\
\hline Mbita & 5.509 & 4.727 & 5.160 & 3.487 & 3.597 \\
\hline Suba & 5.240 & 5.318 & 5.752 & 3.378 & 3.483 \\
\hline County Mean Score & 5.340 & 5.607 & 5.914 & 3.564 & 3.895 \\
\hline
\end{tabular}

Source: MoEST office, Homa Bay County (2018).

The entry mean scores into secondary education for Rachuonyo South Sub-County were 7.408 and 7.836 respectively (2003 \& 2004 cohort). While the exit mean scores from secondary education were 4.146 and 4.091 respectively. This implies that the Sub-County registered academic progresses of -3.262 and -3.745 in the secondary education of 2013 and 2014. Despite registering high drops in academic process, the Sub-County ranks second in Homa Bay County. This informed the current study to determine value addition in the secondary education of 2013 and 2014 cohorts in public secondary schools in Rachuonyo South Sub-county as opposed to the frequent analysis of academic performance, which does not take into consideration the entry academic abilities of learners.

\subsection{Statement of the Problem}

Existing literature focusing on students' academic performance in schools has generally used end year mean scores to judge students' academic performance as well as the basis for judging school effectiveness. However, this method fails to take into account the actual contribution of schools towards students' academic performance. According to David (2010), "judging schools' effectiveness solely on the basis of end-of-year test scores of students without regard to where the students started at the beginning of the year is unfair to school systems". Hence, there is need to determine the contribution of schools towards academic performance of students, taking into consideration the KCPE scores as the entry scores and KCSE scores as the exit scores, using "value added system", which apparently has not been adopted by school systems in many countries since "it is a relatively new approach" (Banister, 2015). Therefore, this study sought to determine value addition in the secondary education of 2013 and 2014 cohorts and to examine selected school based school factors'; teacher performance appraisal, continuous assessments and classroom pull and push factors, influence on value addition in public secondary schools in Rachuonyo South Sub-County.

\subsection{Purpose for the Study}

The purpose for the study was examine selected school based factor' influence on value addition in secondary education of 2013 and 2014 cohorts in public secondary schools in Rachuonyo South Sub-County. 


\subsection{Objectives of the Study}

The study was guided by the following specific objectives:

- To examine teacher performance appraisal's influence on value addition in secondary education.

- To examine continuous assessments' influence on value addition in secondary education.

- To examine classroom push and pull factor's influence on value addition in secondary education

\section{Literature Review}

\subsection{Teacher Performance Appraisal and Value Addition}

Performance Appraisal is a human resource management practice that has been widely studied all over the world and has been identified as a strong motivator for employees in any organization (Ademola, 2017). It is a key ingredient of the whole performance management system used as a parameter for evaluating performance of employees against set standards (Dessler, 2008). It is the evaluation of individual employee traits, behaviours and output in a specified period of time (Karimi, Malik \& Hussain, 2011). It is an ongoing process of identifying, measuring and developing an individual's performance in accordance with an organization's strategic goals (Daoanis, 2012).

Performance appraisal can serve a summative, formative purpose or both (Liu, 2016). Summative evaluation provides conclusive evaluation of a teacher's performance to determine how well that individual has done his or her work (Marzano, 2012). In this type of evaluation, a supervisor evaluates a teacher using a combination of measures that may include student test scores, lesson plans and artifacts, and rating scales or rubrics. Teachers are not involved and the results are used for accountability decisions such as pay awards or dismissal (Marzano, 2012). Formative evaluation on the other hand provides ongoing information about teachers' practices with the goal of providing feedback that helps teachers improve. Teachers are involved in the process through selfreflection or self-assessment. The results of the evaluation may be used to give teachers feedback, and to make decisions regarding professional development or coaching support that teachers receive (Sayavedra, 2014).

Danielson \& McGreal (2011) assert that when performance appraisal is used for accountability and developmental purposes, the one that identifies and enhances teaching quality is the ideal quality assurance mechanism. Moreover, Hay Group (2012) notes that performance appraisal that focuses on teachers' development is the most effective in improving quality of teaching in classrooms. The second objective of the study sought to examine the influence of teacher performance appraisal on value addition in secondary education. Thence, literature in this section focused on performance appraisal, which is geared towards teacher development with the aim of improving learners' academic achievements. 


\subsection{Teacher Performance Appraisal and Professional Development (TPAD)}

Teacher Performance Appraisal and Development (TPAD) framework has seven competency areas, which focus on one teacher trait (professional development) and six teacher behaviors (professional knowledge and application; time management; innovation and creativity in teaching; learner protection, safety, discipline and teacher conduct; promotion of co-curricular activities; and collaboration with parents/guardians and stakeholders (TSC, 2016). Of the seven competency areas, five have a link to students' academic achievements. Table 3 illustrates this.

Table 3: Standards of Teaching (TPAD, 2016)

\begin{tabular}{|l|l|l|}
\hline & Teaching Standard / Competency Area & Competencies / Performance Indicator \\
\hline 1 & $\begin{array}{l}\text { Professional knowledge } \\
\text { and application. }\end{array}$ & Ability to prepare professional records. \\
\hline 2 & Time management. & Ability to manage teaching time. \\
\hline 3 & $\begin{array}{l}\text { Learner protection, safety, discipline } \\
\text { and teacher conduct. }\end{array}$ & $\begin{array}{l}\text { Knowledge of relevant matters e.g. legal, } \\
\text { sexual, psychological, etc. }\end{array}$ \\
\hline 4 & Professional development. & $\begin{array}{l}\text { Ability to identify gaps, training needs and } \\
\text { seek solutions. }\end{array}$ \\
\hline 5 & $\begin{array}{l}\text { Collaboration with parents/ } \\
\text { guardians and stakeholders. }\end{array}$ & $\begin{array}{l}\text { Ability to establish and maintain collaborative } \\
\text { relationships with stakeholders. }\end{array}$ \\
\hline
\end{tabular}

Source: Teachers Service Commission (2016).

The TPAD appraisal and rating criterion anticipates teacher performance in five levels ranging from 'very good' to 'inadequate' performance respectively. The five levels of performance are rated on a five-point Likert scale with five points allocated for performance that meets and exceeds targets while failure to meet set targets is rated the least with one point. The annual rating scores are the average agreed scores between the appraisers and appraisees (TSC, 2016). One performance target in each of the five competency areas links teacher performance with learning achievement. The highest level of performance of the teacher in the five competency areas attracts a maximum of 25 marks (five marks for each performance target). Table 4 illustrates this.

Table 4: Performance Evaluation Criteria and Rating (TPAD)

\begin{tabular}{|l|c|c|c|}
\hline Rating Grade & Rating Indicator & Rating Scale & Annual Rating Scale \\
\hline Very good & Fully met and exceed and exceed the targets & 5 & $81 \%-100 \%$ \\
\hline Good & Fully met the targets & 4 & $61 \%-80 \%$ \\
\hline Average & Met most of the targets & 3 & $41 \%-60 \%$ \\
\hline Below average & Met most of the targets & 2 & $21 \%-40 \%$ \\
\hline Inadequate & Did not meet the targets & 1 & $0 \%-20 \%$ \\
\hline
\end{tabular}

Source: Teacher Performance Appraisal and Development (TSC, 2016).

The dependability of students' learning outcomes on teacher performance appraisal and development (TPAD) appraisal framework is $80 \%$ given that five of the seven competency areas (less 20\%, performance for 3rd and 5th competency areas) are expected to yield the outcome of improved students' test scores. However, the performance 
appraisal tool does not show direct link between improvements in student test scores and teacher performance in specific items within each of the five competency areas. As a result, the performance of each teacher was ascertained by scores in the five targets each with a maximum of five marks.

Teachers' ratings in appraisal process have received mixed reactions from different scholars as regards students' academic achievements. In Chicago State, a study by Sertain et al. (2011) found positive relationship between teachers' ratings and learners' progress. Students taught by teachers rated as distinguished made approximately $30 \%$ progress more than students taught by teachers rated as unsatisfactory. In Zambia, a study by Hadi (2006) indicated that there is no correlation between the supervisors' ratings of teachers and the success of the teachers' students. In Kenya-Narok Sub-County, most of the teacher ratings range from $50 \%$ to $70 \%$. However, when the learners' scores are assessed, they range from $15 \%$ to $60 \%$. This shows that teachers' competencies are above average while that of the learners are below average (Julie, 2012). This raised a question, which the current study sought to address, what influence do teachers' ratings have on value addition in secondary education?

\subsection{Continuous Assessments and Value Addition}

Assessment is a systematic process of collecting information that can be used to make inferences about learners' academic progress (Reynolds, Livingstone \& Wilson, 2009). Assessment is not just about collecting data, but also a process used to appraise students' knowledge, understanding, abilities or skills and is inextricably linked to a course intended learning outcomes (Marriot \& Lau, 2008). According to Lubanga (2010), assessment falls into two broad categories. Fully structured assessment, which has planned mechanisms conducted at regular intervals at the end of the course for primarily summative purposes, generating grades to combine with the scores from a system's official end year examinations. On the other hand, is unstructured assessment, which identifies students' comprehension of a concept, content or technique during instruction in order to make immediate adjustment to instruction and to provide prompt precise feedback to strengthen the learning of students formatively.

Continuous assessment is a formative assessment tool, which informs feedback, remediation and enrich target to students' leaning (Muskin, 2017). Ogunnyi (2014) asserts that continuous assessment is a formative evaluation procedure concerned with finding out, in a systematic manner, the over-all gains that a student has made in terms of knowledge, attitude and skills after a given set of learning experience. Ajuonuma (2010) asserts that continuous assessment is a formative process of gathering and fashioning data into an interpretable form of making decisions about subsequent instruction. From the above definitions, it is deducible that continuous assessment is a formative assessment tool. Thus, this study used continuous assessments and formative assessments interchangeably. 


\subsection{Classroom Push and Pull Factors and Value Addition}

Classroom is the central organizing unit of schools, which arranges students in classes intended to promote learning by allowing teachers and students to interact with different activities that result in learning (Epstein et al., 2008). According to Paradise (2014), the components of classroom include how members of the class communicate, members' expectations of each other, and the degree to which members like and respect one another. These components affect such learning outcomes as attitude, achievements and self-concepts.

Children bring to classroom a number of behaviors and characteristics from home. These coupled with teacher factors can promote or hinder students' academic achievements at the classroom level. This section discussed teacher to students and student-to-student classroom social factors and academic achievements.

The teacher is at the center of classroom interactions that promote social and cognitive developments of learners. They are the agents who impart instructions and monitor the performance and behavior of learners in the classroom. According to William (2012), the position of the teacher is to influence directly or indirectly students' achievement during classroom learning practices. It is thus imperative to consider teacher-to-student relationship as the basis for the social context in which learning takes place.

Positive teacher-to-student relationships improve the classroom climate, which results in more motivation to learn. Students who perceive their teachers as supportive in classroom are more inclined to trust and like those teachers and thus are more motivated to succeed (Asiyai, 2014). When a teacher creates a welcoming classroom climate and considers the needs of the students, learning outcomes will be ideal-students will effectively perform tasks they find important or interesting (Maulana et al., 2013).

Allen et al. (2013) examined the relationship between teacher-student interactions and achievement among secondary school students. Results showed that positive classroom climates characterized by teacher sensitivity, regard for adolescents' perspectives, order and organization, and task-focus significantly predicted students' achievement. Similarly, Perry et al. (2007) examined the effects of average classroom positive relations on first grade achievement in US and found that students achieved higher academic gains on a curriculum-based math test and a higher percentage of students met end-of-year math and reading standards in classrooms where teachers exhibited more support for the students. Wells (2011) reports that positive teacherstudent relationship influence positive self-concepts in students in South Africa. The study further reports positive significant relationship between teachers' interest in students' academic work and academic achievements. 


\section{Research Design and Methodology}

\subsection{Research Design}

According to Brink \& Wood (2004), research design can be named based on the timing of data collection. Studies that focus on events that have occurred in the past are retrospective or ex post facto. Cohen and Manion (2010) assert that ex post facto indicates that data are collected after a presumed cause has occurred. The researcher takes the dependent variable and examines the data retrospectively to find out what factors seem to be associated with certain occurrences. The research design of this study is correlational ex post facto in that the data that were collected focused on students' outcomes at the end of their primary and secondary schooling and so the results relate to a previous period of each school's history. Correlational ex post facto involves the collection of two data sets, one of which is retrospective, with a view of determining the relationship between them (Cohen \& Manion, 2010).

\subsection{Population of Study}

A population is the entire group of elements that have at least one thing in common (Orodho, 2009). The target population is the larger group from which the researcher hopes to generate the findings. For this study, the target populations were 49 public secondary schools in Rachuonyo South Sub-County, 49 Deputy Principals, 49 Directors of Studies and 4351 students.

\subsection{Sample and Sampling Technique}

A sample is part of a target population that has been procedurally selected to represent a population (Oso and Onen, 2009). To arrive at a scientifically reliable sample, the researcher applied Yamane's formula (Yamane, 1967). After determining a sample of 39 public secondary schools, the researcher then employed stratified sampling to partition the sample frame into county and sub-county. The researcher afterwards employed purposive sampling to select 39 Deputy Principals and 39 Directors of Studies from the participating schools. Finally, the researcher employed random sampling to select students from the candidate classes from the sampled schools out of which 10 students represented a cohort apiece, totaling to 780 students.

\subsection{Instruments of Data Collection}

The researcher used the following instruments to collect data from sampled schools for analysis:

\subsubsection{Document Analysis Guide}

The researcher used a Document Analysis Guide to collect data about KCPE and KCSE scores of 2013 and 2014 cohorts. The Document Analysis Guide was structured to collect KCPE and the corresponding KCSE scores of the two cohorts. The documents analyzed 
included 2013 and 2014 form one admission lists to get KCPE scores and 2016 and 2017 $\mathrm{KCPE}$ results printouts to get KCSE scores.

\subsubsection{Questionnaire}

Questionnaire is considered as the heart of survey operation for data collection (Kothari, 2011). The researcher used three questionnaires that contained closed ended questions to elicit information from three groups of respondents in this study.

\subsection{Validity of Research Instruments}

Validity is the extent to which a method of data collection measures what it is supposed to measure (Amin, 2005). Content validity refers to whether a measurement instrument has adequate and representative coverage of the concepts in the variables being measured. According to Mitchell (1996), to establish content validity, researchers must seek experts' opinion on the representativeness and suitability of the measurement instruments and suggestion must be allowed to be made to the structure of the instrument. As such, two university supervisors from the department, Educational Management and Foundations, ascertained the content validity of the document analysis guide and the questionnaires. Unnecessary items were discarded and the document analysis guide and the questionnaires were restructured.

\subsection{Reliability of Research Instruments}

Reliability is a measure to which a research instrument yields consistent results after repeated tries (Mugenda and Mugenda, 2008). Yin (2013) asserts that the goal of reliability is to minimize errors and biases in a study. The questionnaires were administered two times to the same respondents in a span of two weeks and results from both administrations were recorded. Test-retest method was used to establish the reliability of the questionnaires using Pearson's Correlation Coefficient. According to Tavakol \& Dennick (2011), the coefficient value can take any value from 0-1. A coefficient value of 0 implies no internal consistency, while a coefficient value of 1 implies complete internal consistency. Nargundka (2010, p.64), asserts that a scale is usually considered good if the coefficient value is 0.7 or more. Thus, for the current study, coefficient values of .86 for TPAD tool, 0.79 for questionnaire for CAT and 0.82 for WIHICQ were preferred.

\subsection{Data Analysis Procedures}

The purpose for data analysis is making sense of the accumulated data. The researcher must organize what they have seen, heard and read and try to make sense of it in order to create explanations, develop theory or pose new questions (Vithal \& Jansen, 2001). Hence, the researcher analysed data according to the research objectives with the aid of Statistical Package for Social Science (SPSS) version 21 software. 


\section{Results and Findings}

\subsection{Teacher Performance Appraisal and Value Addition}

The objective of the study sought to examine the influence of Teacher Performance Appraisal on Value Addition in secondary education. To address this objective, a measurement scale, Teacher Performance Appraisal and Development framework, TPAD tool was used to collect data about teachers' competencies. The TPAD tool comprised five competency areas, with each competency area targeting teachers' competence. A 5-point Likert scale from: Very Good $(\mathrm{VG})=5 ; \operatorname{Good}(\mathrm{G})=4$; Average $(\mathrm{A})$ $=3$; Below Average $(\mathrm{BA})=2$ and Inadequate $(\mathrm{IA})=1$ was used to measure the competencies. Table 5 summarized the findings.

Table 5: Teacher Performance Appraisal and Development Tool (TPAD)

\begin{tabular}{|l|l|c|c|c|c|c|}
\hline \multirow{2}{*}{ Performance Competency Area } & \multicolumn{5}{|c|}{ Rating } \\
\cline { 2 - 7 } & & IA & BA & A & G & VG \\
\hline \multirow{2}{*}{$\begin{array}{l}\text { Professional knowledge } \\
\text { and application }\end{array}$} & Frequency & 1 & 0 & 2 & 27 & 2 \\
\hline \multirow{2}{*}{\begin{tabular}{l} 
Time management \\
\cline { 2 - 7 }
\end{tabular}} & Percentage & 1.33 & 0.00 & 6.25 & 84.38 & 6.25 \\
\hline \multirow{2}{*}{$\begin{array}{l}\text { Innovation and creativity } \\
\text { in teaching }\end{array}$} & Frequency & 1 & 1 & 2 & 27 & 1 \\
\hline \multirow{2}{*}{\begin{tabular}{l} 
Professional development \\
\cline { 2 - 7 }
\end{tabular}} & Percentage & 3.13 & 3.13 & 6.25 & 84.38 & 3.13 \\
\hline \multirow{2}{*}{$\begin{array}{l}\text { Collaboration with } \\
\text { parents or guardians }\end{array}$} & Percentage & 0.00 & 12.50 & 37.50 & 43.75 & 6.25 \\
\cline { 2 - 7 } & Frequency & 1 & 2 & 8 & 16 & 5 \\
\hline
\end{tabular}

Source: Research data (2019).

Table 5 illustrates that most Deputy Principals (84.4\%) indicated that teachers had good professional knowledge and application, (84.4\%) indicated that teachers had good time management practices, $(31.25 \%)$ indicated that teachers had good levels of innovation and creativity in teaching, (50\%) indicated that teachers had good professional development records and (56.25\%) indicated that teachers had good records of collaboration with stakeholders and parents.

\subsection{Continuous Assessment Tests and Value Addition}

The third objective of the study sought to examine the influence of Continuous Assessment on value addition in secondary education. To address this objective, two measurement scales with multiple question items were selected and rated on different Likert scales.

The first measurement scale sought to find out the interval of implementing continuous assessment practices in public secondary schools in Rachuonyo South SubCounty. To address this objective, a measurement scale with eleven question items was selected and rated on a 5-point Likert scale from $1=$ Termly $(\mathrm{T}) ; 2=$ Half-termly $(\mathrm{T} / \mathrm{H}) 3=$ Monthly (M); 4 = Weekly (W) $5=$ Daily (D. Table 6 summarized the findings. 
Table 6: Continuous Assessment Practice

\begin{tabular}{|c|c|c|c|c|c|c|}
\hline \multirow{2}{*}{ Question Items } & \multirow{2}{*}{ Interval } & \multicolumn{5}{|c|}{ Scale } \\
\hline & & $T$ & $\mathrm{H} / \mathrm{T}$ & $\mathbf{M}$ & $\mathbf{W}$ & D \\
\hline \multirow{2}{*}{ Administering oral tests. } & Frequency & 0 & 0 & 2 & 19 & 11 \\
\hline & Percentage & 0.00 & 0.00 & 6.2 & 58.8 & 34.8 \\
\hline \multirow{2}{*}{ Administering recap exercises. } & Frequency & 1 & 2 & 3 & 17 & 9 \\
\hline & Percentage & 3.13 & 6.25 & 9.38 & 53.13 & 28.13 \\
\hline \multirow{2}{*}{ Administering assignments. } & Frequency & 0 & 0 & 1 & 10 & 21 \\
\hline & Percentage & 0.00 & 0.00 & 3.1 & 31.2 & 65.62 \\
\hline \multirow{2}{*}{ Administering written tests. } & Frequency & 6 & 17 & 3 & 4 & 2 \\
\hline & Percentage & 19 & 43.80 & 3.10 & 37.50 & 15.60 \\
\hline \multirow{2}{*}{ Assessing specific course objectives. } & Frequency & 7 & 6 & 5 & 4 & 10 \\
\hline & Percentage & 21.88 & 18.75 & 15.63 & 12.50 & 31.25 \\
\hline \multirow{2}{*}{$\begin{array}{l}\text { Making sure assessments adequately cover } \\
\text { the material taught. }\end{array}$} & Frequency & 1 & 3 & 2 & 11 & 15 \\
\hline & Percentage & 3.13 & 9.38 & 6.25 & 34.38 & 46.88 \\
\hline \multirow{2}{*}{$\begin{array}{l}\text { Developing rubrics (marking keys) for objectively } \\
\text { grading students' performance in continuous } \\
\text { assessments. }\end{array}$} & Frequency & 0 & 10 & 6 & 8 & 8 \\
\hline & Percentage & 0.00 & 31.00 & 19.00 & 25.00 & 25.00 \\
\hline \multirow{2}{*}{$\begin{array}{l}\text { Determining why students } \\
\text { make specific mistakes. }\end{array}$} & Frequency & 0 & 3 & 3 & 12 & 14 \\
\hline & Percentage & 0.00 & 9.38 & 9.38 & 37.50 & 43.75 \\
\hline \multirow{2}{*}{$\begin{array}{l}\text { Using continuous assessements' results for decision } \\
\text { making about individual student's learning needs. }\end{array}$} & Frequency & 2 & 2 & 12 & 8 & 8 \\
\hline & Percentage & 6.25 & 6.25 & 37.50 & 25.00 & 25.00 \\
\hline \multirow{2}{*}{$\begin{array}{l}\text { Using continuous assessments' results in designing } \\
\text { appropriate teaching methodology for students. }\end{array}$} & Frequency & 4 & 11 & 11 & 3 & 3 \\
\hline & Percentage & 12.50 & 34.25 & 34.38 & 9.38 & 9.38 \\
\hline
\end{tabular}

Source: Research data (2019).

Table 6 illustrates that of the 39 Directors of Studies surveyed: (58.8\%) administered oral tests on weekly and half term bases; (53.13\%) administered recap exercises on weekly basis; (65\%) administered assignments on daily basis; (43.8\%) administered written tests on half term basis; $31.25 \%$ of the teachers assess specific course objectives on daily basis; $46.88 \%$ of teachers make sure assessments adequately cover the material taught on daily basis; $50 \%$ of teachers develop rubrics (marking keys) for objectively grading students' performance in continuous assessments on both weekly and daily bases; $(43.75 \%)$ determine why students make specific mistakes on daily basis and (37\%) use continuous assessments' results for decision making about individual student's learning needs on monthly basis.

The second measurement scale sought to find out the frequency of implementing continuous assessment feedback practices by teachers in public secondary schools in Rachuonyo South Sub-County. To address this objective, a measurement scale with ten question items was selected and rated on a 5-point Likert scale from $5=$ Very Often (VO); $4=$ Often $(\mathrm{O}), 3=$ Uncertain $(\mathrm{U}) ; 2=\operatorname{Rarely}(\mathrm{R})$ and $1=$ Almost Never(AN). Table 7 summarized the findings. 
Table 7: Continuous Assessment Feedback Practice

\begin{tabular}{|c|c|c|c|c|c|c|}
\hline \multirow{2}{*}{ Question Items } & \multirow[b]{2}{*}{ Frequency } & \multicolumn{5}{|c|}{ Scale } \\
\hline & & VO & $\mathrm{O}$ & $\mathrm{U}$ & $\mathbf{R}$ & AN \\
\hline \multirow{2}{*}{$\begin{array}{l}\text { Analyzing completed work to determine why a } \\
\text { pupil has or has not achieved. }\end{array}$} & Frequency & 8 & 12 & 0 & 12 & 0 \\
\hline & Percentage & 25.00 & 37.5 & 0.00 & 37.5 & 0.00 \\
\hline \multirow{2}{*}{$\begin{array}{l}\text { Giving rewards when achievement is satisfactory } \\
\text { for that pupil with specific comments referring to } \\
\text { that pupil. }\end{array}$} & Frequency & 1 & 1 & 4 & 20 & 6 \\
\hline & Percentage & 3.13 & 3.13 & 12.5 & 62.50 & 18.75 \\
\hline \multirow{2}{*}{$\begin{array}{l}\text { Expressing approval when achievement } \\
\text { is satisfactory. }\end{array}$} & Frequency & 21 & 10 & 1 & 0 & 0 \\
\hline & Percentage & 65.63 & 31.25 & 3.13 & 0.00 & 0.00 \\
\hline \multirow{2}{*}{$\begin{array}{l}\text { Making a conscious decision to avoid saying a } \\
\text { pupil is wrong. }\end{array}$} & Frequency & 17 & 2 & 3 & 1 & 9 \\
\hline & Percentage & 53.13 & 6.25 & 9.38 & 3.13 & 28.13 \\
\hline \multirow{2}{*}{$\begin{array}{l}\text { Telling students what they have achieved with } \\
\text { specific reference to their learning. }\end{array}$} & Frequency & 10 & 13 & 2 & 7 & 0 \\
\hline & Percentage & 31.25 & 40.63 & 6.25 & 21.88 & 0.00 \\
\hline \multirow{2}{*}{$\begin{array}{l}\text { Telling students what they have not achieved } \\
\text { with specific reference to their learning. }\end{array}$} & Frequency & 12 & 14 & 0 & 4 & 2 \\
\hline & Percentage & 37.50 & 43.75 & 0.00 & 4.12 .50 & 6.25 \\
\hline \multirow{2}{*}{$\begin{array}{l}\text { Describing why an answer is } \\
\text { correct. }\end{array}$} & Frequency & 11 & 17 & 0 & 3 & 1 \\
\hline & Percentage & 34.38 & 53.38 & 0.00 & 9.38 & 3.13 \\
\hline \multirow{2}{*}{$\begin{array}{l}\text { Specifying a better or differrent way of doing } \\
\text { something. }\end{array}$} & Frequency & 8 & 19 & 1 & 4 & 0 \\
\hline & Percentage & 25 & 59.38 & 3.13 & 12.50 & 0.00 \\
\hline \multirow{2}{*}{$\begin{array}{l}\text { Writing an evaluative note on } \\
\text { a pupil's work for the pupil. }\end{array}$} & Frequency & 10 & 13 & 2 & 7 & 2 \\
\hline & Percentage & 31.25 & 40.63 & 6.25 & 21.88 & 0.00 \\
\hline \multirow{2}{*}{$\begin{array}{l}\text { Using students' results to } \\
\text { monitor learning progress. }\end{array}$} & Frequency & 12 & 14 & 0 & 4 & 2 \\
\hline & Percentage & 37.50 & 43.75 & 0.00 & 12.50 & 6.25 \\
\hline
\end{tabular}

Source: Research data (2019).

Table 7 illustrates that of the 39 Directors of Studies surveyed: (62.5\%) rarely give rewards to pupils when achievement is satisfactory with specific comments referring to that pupil; $65 \%$ often express approval when achievement is satisfactory; (53.1\%) often make conscious decisions to avoid saying a pupil is wrong; (40\%) often tell students what they have/not achieved with specific reference to their learning; (53.13\%) often describe why an answer is correct; (59\%) often specify a better or different way of doing something; $(40.63 \%)$ write an evaluative note on a pupil's work for the pupil and $(43.75 \%)$ use students' results to monitor learning progress.

\subsection{Classroom Push and Pull Factors and Value Addition}

The fourth objective of the study sought to examine the influence of classroom push and pull factors on value addition in secondary education. To address this objective, a measurement scale with seven question items was selected and rated on a 5-point Likert scale from 1 = Almost Never (AN); 2 = Sometimes (SM); 3 = Uncertain (U); 4 = Often $(\mathrm{OFTN}) ; 5$ = Almost Always (AA). Table summarized the findings. 


\begin{tabular}{|c|c|c|c|c|c|}
\hline \multicolumn{6}{|c|}{ Table 8: Classroom Push and Pull Factors } \\
\hline Question items & $\mathbf{A N}$ & SMT & UN & OFTN & AA \\
\hline $\begin{array}{l}\text { Students are friendly and supportive to each } \\
\text { other in class. }\end{array}$ & $\begin{array}{c}2 \\
6.3 \% \\
\end{array}$ & $\begin{array}{c}7 \\
21.9 \% \\
\end{array}$ & $\begin{array}{c}2 \\
6.3 \% \\
\end{array}$ & $\begin{array}{c}6 \\
18.8 \% \\
\end{array}$ & $\begin{array}{c}15 \\
46.6 \% \\
\end{array}$ \\
\hline $\begin{array}{l}\text { Teachers help and are interested in students' } \\
\text { welfare and academic progress. }\end{array}$ & $\begin{array}{c}2 \\
6.3 \% \\
\end{array}$ & $\begin{array}{c}4 \\
12.5 \% \\
\end{array}$ & $\begin{array}{c}1 \\
3.1 \% \\
\end{array}$ & $\begin{array}{c}12 \\
37.5 \% \\
\end{array}$ & $\begin{array}{c}13 \\
40.6 \% \\
\end{array}$ \\
\hline $\begin{array}{l}\text { Students have attentive interest, participate } \\
\text { in class and are involved with other students. }\end{array}$ & $\begin{array}{c}1 \\
3.1 \% \\
\end{array}$ & $\begin{array}{c}13 \\
40.6 \% \\
\end{array}$ & $\begin{array}{c}5 \\
15.6 \% \\
\end{array}$ & $\begin{array}{c}3 \\
9.4 \%\end{array}$ & $\begin{array}{c}10 \\
31.3 \%\end{array}$ \\
\hline $\begin{array}{l}\text { Students carry out investigations in different } \\
\text { tasks to test their ideas in problem solving. }\end{array}$ & $\begin{array}{c}0 \\
00 \%\end{array}$ & $\begin{array}{c}14 \\
43.8 \%\end{array}$ & $\begin{array}{c}1 \\
3.1 \%\end{array}$ & $\begin{array}{c}12 \\
37.5 \%\end{array}$ & $\begin{array}{c}5 \\
15.6 \%\end{array}$ \\
\hline $\begin{array}{l}\text { Students' complete classroom tasks and } \\
\text { stay on subject matter. }\end{array}$ & $\begin{array}{c}2 \\
6.3 \% \\
\end{array}$ & $\begin{array}{c}11 \\
34.4 \% \\
\end{array}$ & $\begin{array}{c}2 \\
6.3 \% \\
\end{array}$ & $\begin{array}{c}11 \\
34.4 \% \\
\end{array}$ & $\begin{array}{c}6 \\
18.8 \% \\
\end{array}$ \\
\hline $\begin{array}{l}\text { Students cooperate with each other } \\
\text { in discussions during classroom tasks. }\end{array}$ & $\begin{array}{c}1 \\
3.1 \%\end{array}$ & $\begin{array}{c}3 \\
9.4 \%\end{array}$ & $\begin{array}{c}2 \\
6.3 \% \\
\end{array}$ & $\begin{array}{c}10 \\
31.3 \%\end{array}$ & $\begin{array}{c}16 \\
50 \%\end{array}$ \\
\hline $\begin{array}{l}\text { Teachers treat students equally, including } \\
\text { distributing praise, questions and opportunities } \\
\text { to be included in discussions. }\end{array}$ & $\begin{array}{c}0 \\
00 \% \%\end{array}$ & $\begin{array}{l}3 \\
9.4 \%\end{array}$ & $\begin{array}{c}14 \\
43.8 \%\end{array}$ & $\begin{array}{c}9 \\
28.1 \%\end{array}$ & $\begin{array}{c}9 \\
28.1 \%\end{array}$ \\
\hline
\end{tabular}

Source: Research data, 2019.

Table 7 illustrates that of the 780 students surveyed: (46.6\%) indicated that almost always students are friendly and supportive to each other in class; $(40.6 \%)$ indicated that teachers almost always help and are interested in students' welfare and academic progress. This implied that teachers in public secondary schools in Rachuonyo South Sub-County relate with students positively at classroom level and consider the needs of the students, which consequently create positive classroom climates that support learners' academic achievements. This finding concurs with the findings of Allen et al. (2013), which showed that positive classroom climates characterized by teacher sensitivity, regard for adolescents' perspectives, order and organization, and task-focus significantly predicted students' achievement.

Moreover, (40.6\%) indicated that students sometimes and another $(31.3 \%)$ indicated almost always have attentive interest, participate in class and are involved with other students. This implied that students have positive relations with peers and their behaviors toward academic tasks at classroom level support their academic achievements. This finding concurs with the findings of Nelson \& DeBaker (2008), which demonstrated adaptive achievement in classrooms where teens had good quality friendships and classmates who valued academics.

Finally, (43.8\%) indicated that sometimes and another $(37.4 \%)$ indicated that often students carry out investigations in different tasks to test their ideas in problem solving; $(34.4 \%)$ indicated that sometimes and another $(34.4 \%)$ indicated that often students complete classroom tasks and stay on the subject matter; (50\%) indicated that students almost always and another (31.3\%) indicated that often students cooperate with each other in discussions during classroom tasks and (43.8\%) were uncertain that teachers treat students equally, including distributing praise, questions and opportunities to be included in discussion. 


\section{Conclusions}

The study found an insignificant positive relationship between continuous assessment tests and value addition in secondary education of 2013 cohort. This implied that continuous assessment tests and value addition are statistically non-dependent. Consequently, a conclusion was made that value addition in secondary education is explained by other school-based factors other than continuous assessment tests. This means that if teacher performance appraisal practices increase, value addition also increases. The study found a strong and significant positive relationship between teacher performance appraisal and value addition in secondary education of 2013 and 2014 cohorts. This implied that teacher performance appraisal and value addition are statistically dependent. Thus, a conclusion was made to the effect that value addition in education is predictive on teacher performance appraisal.

\subsection{Recommendations}

The study recommends that schools should consciously promote active monitoring and supervision of its academic programmes and institutionalise continuous self-evaluation by both staff and its students. When monitoring the progress of students, each student's prior attainment in a particular subject must be taken into account. By focussing on the subject results as well as the overall effectiveness, the school academic department can identify strengths and weaknesses and appropriate measures be employed to improve academic progress. Therefore, the study recommends that performance appraisal and development framework include more classroom observations from one and adopt multiple classroom observations like the Tennessee System of continuous multiple classroom based teacher evaluation. The study therefore recommends that teachers should sufficiently discuss continuous assessment results with individual students to demystify possible difficult areas.

\subsection{Area for Further Research}

The researcher therefore recommends that a longitudinal study spanning four years of secondary education be undertaken to enable researchers determine the causal links between school based factors and value addition. The study therefore recommends a research on multiple classroom observations with immediate feedback to teachers in a term and its influence on value addition. The current study focused on the interval for implementing continuous assessment practices and the frequency of implementing continuous assessment feedback practice's influence on value addition in secondary education. The study therefore recommends a study on continuous assessments data's influence on value addition in secondary education.

\section{Conflict of Interest Statement}

The authors declare no conflicts of interests. 


\section{About the Authors}

Felix Elmands is currently a student at Maseno University pursuing Masters of Education in Planning and Economics of Education. Currently, teaching in secondary school with Teachers Service Commission in Homa Bay County, Kenya.

Dr. James Ochieng Sika is currently a Senior Lecturer in the Department of Education Management and Foundation specialized in planning and Economics of Education. Previously worked with Ministry of Education and with Teacher Service Commission.

\section{References}

Ademola, S. (2017). Impact of Performance Appraisal on Employee Performance. International Journal of Economics and Business Management vol.3 (1) 80-90

Agarwal, P. K., Bain, P., \& Chamberlain, R. (2012). The value of applied research: Retrieval practice improves classroom learning and recommendations from a teacher, a principal, and a scientist. Educational Psychology Review, 24(3)

Allen, D. A., \& Fraser, B. J. (2007). Parent and Student Perceptions of Classroom Learning Environment and its Association with Student Outcomes. Learning Environments Research, 10, 67-82. Doi:10.1007/s10984-007-9018-z

Amutabi, M. N. (2003). Political interference in the Running of Education in PostIndependence Kenya: A Critical Retrospection. International Journal of Educational Development. 23: 127-144

Araujo, M. C., Carneiro, P., Cruz-Aguayo, Y., \& Schady, N (2014). A Helping Hand? Teacher Quality and Learning Outcomes in Kindergarten. Banco Interamericano de Dessarollo, Washington DC Inedi'to.

Asiyai, R. (2014). Students' Perception of the Condition of Their Classroom Physical Learning Environment and Its Impact on Their Learning and Motivation. College Student Journal, 48(4), 716-726.

Bell.C. A, Y. Qi, A. J. Croft, D. Leusner, D. F. McCaffrey, D. H. Gitomer (2012). Improving Observational Score Quality, Jossey-Bass, San Francisco, CA (2014).

Bennett, R. E. (2011). Formative Assessment: A critical review. Assessment in Education: Principles, Policy and Practice 18, 5-25.

Boynton, M. \& Boynton, C. (2005). Developing Positive Teacher-Student Relationships. Educator's Guide to Preventing and Solving Discipline Problems. Retrieved from http://www.ascd.org/publications/books/105124/chapters/Developing Positive T eacher Student Relations.aspx

Browne, E. (2016). Evidence on Formative Classroom Assessment for Learning. K4D Helpdesk Report. Brighton, UK: Institute of Development Studies

Cohen, J. McCabe, E. M., Michelli, N. M. \& Pickeral T. (2009). School Climate: Research, Policy, Teacher Education and Practice. Retrieved from https://eric.ed.gov/?id=EJ826002 
Coleman, J. S., Campbel E., Hobson, C., McPartland, J., Mood, A, Weinfeild, F. and York, R. (1966). Equality of Educational Opportunity. Washington DC: US Government Press

Cunha, J. and Miller, D. (2009). Value-Added in Higher Education, 30 April 2009, Retrieved from http://www.stanford.edu/ millerdw/value added.pdf

Danielson, C. \& McGreal, T. L. (2010). Teacher evaluation: To enhance professional practice. Alexandria, VA: Association for Supervision and Curriculum Development. Retrieved from https://www.ascd.org/books/teacher-evaluation-to-enhanceprofessional-practice

Daoanis, L. E. (2012). Performance Appraisal System: It's Implication to Employee Performance. International Journal for Economics and Management. Retrieved from https://www.semanticscholar.org/paper/PERFORMANCE-APPRAISALSYSTEM-\%3A-It-\%E2\%80\%99-s-ImplicationDaoanis/c9b4c1089ba2d9e6f4de68da13918d556ceecbd7

Downes, D., \& Vindurmapulle, O. (2007). Value-added measures for school improvement. Melbourne, Australia. Education Policy and Research Divisions: Office of Education Policy and Innovation.

Epstein, M., Atkins, M., Cullman, D., Kutash, K.\& Weaver. (2008). Reducing 94 Behaviour Problems in Elementary School Classroom. A Practice Guide (NCEEU2008-012). Washington DC, National Centre for Education Evaluation and Regional Assistance, Institute of Education Sciences, US Department of Education.

Gathumbi, A., W. N. J, \& Mungai, N. J. \& Hanitez, D. L. (2013). Towards Comprehensive Professional Development for Teachers: The case of Kenya. International Journal of press education. Retrieved from https://irlibrary.ku.ac.ke/handle/123456789/13491

Goe, L., Biggers K. \& Croft, A. (2012). Linking teacher evaluation to professional development: Focusing on Improving Teaching and Learning. Retrieved from https://eric.ed.gov/?id=ED532775

Hadi A. (2006). The Relationship between Teachers' Performance Ratings and the Achievement of their Students Education. Organization of Zanjan. Applied H.R.M. Research, Volume 11, (1): 75-78. Julie

Hattie, J. (2009). Visible learning: A synthesis of over 800 Meta Analyses Relating to Achievement. London, England: Routledge.

Hay Group (2012). Growing our Potential: Hay Group's view on Implementing an Effective Performance Improvement and Development Framework for Teachers. Melbourne, Vic.: Hay Group.

Institute of Economic Affairs (2017). Comparative Analysis of KCSE performance. Retrieved from www.ieakenya.or.ke/number of the week/comparative-analysis-of-kcseperformance

JICA (2013. Kenya SMASSE/SMASE projects (1998-2013).

Julie, A. N. (2012). Effects of Teacher Evaluation on Teachers Effectiveness and Student Achievement. A published MED thesis, Northern Michigan University. 
Kenya National Examinations Council (KNEC) (2013). Kenya Certificate examination Report. Nairobi: Kenya National Examinations Council.

Kiplagat P. (2016). Rethinking Primary School Mathematics teaching: A Formative assessment approach. Baraton Inter-Disciplinary Research Journal (2016), 6(Special Issue) $p$ p 32-38.

Koth, C. W., Bradshaw, C. P., \& Leaf, P. J. (2008). A multilevel study of Predictors of Student Perceptions of School Climate: The effect of Classroom-level Factors. Journal of Educational Psychology, 100, 96 - 104

Kyriakides, L., \& Luyten, H. (2009). The contribution of schooling to the cognitive development of secondary education students in Cyprus: An application of regression discontinuity with multiple cut off points. School Effectiveness and School Improvement, 20(2)

LaRocque, M. (2008). Assessing perceptions of the environment in elementary classrooms: The Link with Achievement. Educational Psychology in Practice, 24(4), 289305.

Lau, C. (2016). Formative good? Summative bad? - A Review of the Dichotomy in Assessment Literature. Journal of Further and Higher Education, 40(4), PP.509-525.

Liu, O. L. (2011). Value-added assessment in higher education: A comparison of Two Methods. Higher Education, 61, 445-461.

McDaniel, M. A., Agarwal, P. K., Huelser, B. J., McDermott, K. B., \& Roediger, H. L. (2011). Test-enhanced learning in a middle school science classroom: The Effects of Quiz Frequency and Placement. Journal of Educational Psychology, 103(2), 399414. doi:10.1037/a002178),

Marzano, R. J. (2012). Teacher Evaluation: What's fair? What's effective? The Two Purposes of Teacher Evaluation. Educational Leadership, 70(3), 14-19. Alexandria, VA: ASCD.

McMillan, J. H. (2014). Classroom assessment: Principles and Practice for Effective Standards Based Instruction (5th ed.). Essex: Pearson

Miller, D., \& Lavin, F. (2007). But now I feel I want to give it a try: Formative assessment, self-esteem, and a sense of competence. The Curriculum Journal, 18(1), 3-25. http://dx.doi.org/10.1080/09585170701292109.

MoEST, (2016). Homa Bay County Education Report, KCSE Analysis. Unpublished.

MoEST, (2016). Rachuonyo South Sub-County Education Report, KCSE Analysis. Unpublished

Montgomery, D. (2012). Positive Teacher Appraisal through Classroom Observation. London: Routledge.

Mwebaza, M. (2016). Continuous Assessment and Students' Performance in 'A' level Schools in Masaka District. A dissertation for award of Masters of Education in Curriculum teaching and media studies, Makerere University, Kampala Uganda.

Nelson, R. M., \& DeBacker, T. K. (2008). Achievement Motivation in Adolescents: The Role of Peer Climate and Best Friends.

Ogundokun, M. O., \& Ogundele, T. O. (2012). Relationship between Continuous Assessment and Academic Performance of Secondary School Students in English 
Language and Mathematics in Ibadan. African Journal for the Psychological Study of Social Issues.15(1).

Opdenakker, M.-C., \& Van Damme, J. (2000). Effects of schools, teaching staff and classes on achievement and well-being in secondary education: Similarities and Differences between School Outcomes. School Effectiveness and School Improvement, 11(2), 165196.

Onyara, B. N. (2013). School Based factors influencing students' academic performance at Kenya certificate of secondary education in Teso South District. Unpublished Thesis, University of Nairobi

Onyehalu, J. (2014). Engaging youth in schools: Empirically-based models to guide the feature innovations. A Handbook for National society for the study of education (NSSE).

Peng, W. J., Thomas, S. M., Yang, X., \& Li, J. (2006). Developing School Evaluation Methods to Improve the Quality of Schooling in China: A pilot "value added" study. Assessment in Education: Principles, Policy and Practice, 13(2), 135-154

Plessis, J., Prouty, D., Schubert, J., Habib, M., \& Eileen, G. (2009). Continuous Assessment: A Practical Guide for Teachers. USAID: Office of Education.

Republic of Kenya (2014). National Education Sector Plan (NESP), Nairobi: Ministry of Education Science and Technology.

Reynolds, D., \& Teddlie, C. (2009). The Processes of School Effectiveness. In Teddlie, C., \& Reynolds, D. (eds.) The International Handbook of School Effectiveness Research (pp135-159). London: Falmer Press.

Samoff, J. (2007). Education Quality: The disabilities of aid. International Review of Education.

Sayavedra, M. (2014). Teacher Evaluation. ORTESOL Journal, 31, 1-9.

Shavelson, R. J. (2006). On The Integration of Formative Assessment in Teaching and Learning: Implications for New Pathways in Teacher Education. In F. Oser, F. Achtenhagen, \& U. Spours, K.; Hodgson, A. 1996.Value-added and raising attainment-a formative approach. London, Institute of Education

Shirvani, H. (2009). Examining an assessment strategy on high school mathematics achievement: Daily quizzes vs. weekly tests. American Secondary Education, 38(1), 3445.

Shute, V. J. (2008). Focus on formative feedback. Review of Educational Effects, 78(1), 153-189. http://dx.doi.org/10.3102/0034654307313795

Smylie, Mark A. (2014) Teacher Evaluation and the Problem of Professional Development MidWestern Educational Researcher, v26 n2 p97-111 2014

Song J, Bong M, Lee K, Kim S-i. Longitudinal investigation into the role of perceived social support in adolescents' academic motivation and achievement. Journal of Educational Psychology $2015 ; 107(3)$ :

Spours K., Hodgson A. (1996). Value Added and Raising Achievement: A Formative Approach. London: Institute of Education. 
Teachers Service Commission (2016). Teacher Performance Appraisal and Development Tool. Retrieved from https://www.tsc.go.ke/ (Accessed on 20th May, 2017).

Tyler E. S. (2011). The Effect of Evaluation on Performance: Evidence from Longitudinal Student Achievement Data of Mid-Career Teachers, NBER Working Paper Series, No. 16877, National Bureau of Economic Research, Cambridge, Massachusetts. Retrieved from https://ideas.repec.org/p/nbr/nberwo/16877.html

Wang, M. \& Holcombe, R. (2010). Adolescents' perceptions of school environment, engagement, and academic achievement in middle school. American Educational Research Journal, 47(3), 633-662. doi: 10.3102/0002831209361209

Zhang, X., \& Ng, H. (2017). An Effective Model of Teacher Appraisal: Evidence from secondary schools in Shanghai, China. Educational Management Administration $\mathcal{E}$ Leadership, 45(2), 196-218 

will be applied to their work. Under the terms of this license, no permission is required from the author(s) or publisher for members of the community to copy, distribute, transmit or adapt the article content, providing a proper, prominent and unambiguous attribution to the authors in a manner that makes clear that the materials are being reused under permission of a Creative Commons License. Views, opinions and conclusions expressed in this research article are views, opinions and conclusions of the author(s). Open Access Publishing Group and European Journal of Education Studies shall not be responsible or answerable for any loss, damage or liability caused in relation to/arising out of conflicts of interest, copyright violations and inappropriate or inaccurate use of any kind content related or integrated into the research work. All the published works are meeting the Open Access Publishing requirements and can be freely accessed, shared, modified, distributed and used in educational, commercial and non-commercial purposes under a Creative Commons Attribution 4.0 International License (CC BY 4.0). 